\title{
ECOLOGICAL RISK ASSESSMENT IN THE REGULATED WATERCOURSES
}

\author{
Elżbieta Bondar-Nowakowska', Justyna Hachoł' \\ 1 Institute of Environmental Protection and Development, Wrocław University of Environmental and Life \\ Sciences, Plac Grunwaldzki 24, 50-363 Wrocław, Poland, e-mail: justyna.hachol@up.wroc.pl
}

Received: 2015.09.16

Accepted: 2015.10 .06

Published: 2015.11 .10

\begin{abstract}
Ecological risk has not been identified well enough for the designers and contractors to take any actions for its limitation. It results from the lack of the basis formed to assess its level objectively. The aim of this study was to determine the standards useful in the evaluation of the ecological risk for aquatic plants in rivers, where it is planned to conduct regulatory works. The basis for the analysis were the results of the study performed in 2008-2014 in unmodified and transformed lowland watercourses in Lower Silesia. 41 study sections were analysed in 11 watercourses. 30 sections were located in regulated watercourses, while 11 were in unmodified streams. The research included vascular aquatic plants identification and the degree of the bottom coverage by these plants. As a result of regulatory works qualitative and quantitative changes in aquatic plants communities were observed. The analysis of these changes concerning the range and conditions of works conduction enabled assigning measures to the factors of the considered risk. It served as a basis for describing the risk register and the matrix of risk. The study demonstrated that the most important threats resulting from the river regulation from the point of view of environmental protection are complete shading of watercourse bed, and in some cases, bed widening and deepening, embankments slope of $1: 1,1: 0$, embankments protection with stone material or their concreting.
\end{abstract}

Keywords: aquatic vascular plants, ecological risk, river, regulation.

\section{INTRODUCTION}

Risk is the degree of exposure to adverse events and their possible consequences [Pritchard 2011]. Risk is determined by three factors - an event of the risk, the probability of its occurrence and the results of the event. Event risk indicates the type of the risk. In turn, the probability of this event occurrence and its consequences affect the level of risk. In case of ecological risk, the size of these two factors is most often determined qualitatively. This creates some problems, since the phrases such as "high probability" or "moderate consequences" might be interpreted differently. The source of discrepancies in this range is, inter alia, the lack of standards of these values evaluation.

The aim of this study is an attempt of determination of such standards in relation to the risk of vascular aquatic plants changes, and an evaluation of that risk in watercourses beds, where it is planned to conduct the regulatory works. This is a partial ecological risk associated with the construction and use of water management equipment and systems.

Regulatory works in small lowland watercourses usually involve:

- total or partial removal of shrubs and trees from the banks and the bank area of the watercourse,

- change in the cross-section of bank including its widening, deepening and proving proper slope to the embankments,

- strengthening of the bottom and embankments. Turf, fascine, stone or concrete material are used for this purpose.

These works are a strong interference in the bed of the watercourse. Their result in the changes in bed biocenosis, often negatively evaluated by the ecologists [Cortes et al. 2002, Petkovska and 
Urbanič 2015]. Therefore, when planning regulatory works, it is simultaneously advisable to develop environmental risk management plan. Such a plan can contribute to reduction or partial elimination of risk, and also cause the need to develop alternative technical solutions. This is reflected in limitation of adverse changes in the natural environment [Bondar-Nowakowska 2010].

The development of risk management plan requires, inter alia, an identification of risk events, risk classification, risk measurements, and planning of the methods for responding to the risk. This study refers to the stage of risk measurement, i.e. an evaluation of the probability of changes occurrence in aquatic plant communities and their size. The following were accepted as the assumed risk events:

- technical actions in the bed of the watercourse,

- probability (possibility) of quantitative changes occurrence in vascular aquatic plants communities as a result of these actions $-P$,

- changes in the number of species caused by the regulatory works $-S$.

The choice of the aquatic plants for the analysis results from their importance in the watercourse's ecosystem. Aquatic plants provide organic matter to the water ecosystem, create suitable environmental conditions and create habitats for other water organisms. They influence a hydrochemistry of the watercourses, have a beneficial impact on a watercourse's ability to self-purification, decrease the intensity of water erosion at the bottom as well as of banks, and promote substrate stabilization [Biggs 1996, Collier 2002, Vereecken et al. 2006]. Aquatic plants also play a role in engineering river channels [SandJensen 1998, O'Hare et al. 2011]. Well-developed plant networks are used to elevate water levels to decrease the hydraulic throughput of a river bed.

\section{STUDY OBJECTS AND METHODS}

The basis for the study are the results of direct field research. They were performed in the years 2008-2014 on 11 small and medium-sized watercourses of Lower Silesia (Table 1).

Regulatory works were performed in these watercourses in the period preceding the study, mostly from 4 to 6 years. The study included 30 sections of a length of $100 \mathrm{~m}$, transformed as a result of the works. Each of these sections corresponded to the bed section not covered by tech-
Table 1. Study objects

\begin{tabular}{|c|c|c|c|}
\hline \multirow[t]{2}{*}{ River } & \multirow{2}{*}{$\begin{array}{l}\text { Length } \\
{[\mathrm{km}]}\end{array}$} & \multicolumn{2}{|c|}{$\begin{array}{l}\text { Number of the study } \\
\text { sections }\end{array}$} \\
\hline & & unmodified & regulated \\
\hline Czarna Woda & 43.8 & 1 & 5 \\
\hline Dobra & 36.1 & 1 & 3 \\
\hline Oleszna & 19.7 & 1 & 2 \\
\hline Oleśnica & 46.6 & 1 & 1 \\
\hline Orla & 95.1 & 1 & 1 \\
\hline Potok Sulistrowicki & 14.7 & 1 & 2 \\
\hline Sąsiecznica & 43.8 & 1 & 4 \\
\hline Smortawa & 39.0 & 1 & 3 \\
\hline Ślęza & 84.1 & 1 & 3 \\
\hline Żalina & 10.9 & 1 & 2 \\
\hline Żurawka & 27.5 & 1 & 4 \\
\hline \multicolumn{2}{|l|}{ Total } & 11 & 30 \\
\hline
\end{tabular}

nical interference. It was a reference point for an evaluation of the changes in the bed caused by the regulation. Research sections were located in the areas with similar physiographic conditions. The bank zone of most research sections was utilized for agricultural purposes. Grasslands and arable lands were predominant. Waters in the examined watercourses were not contaminated with sewage.

A detailed inventory of the elements of the watercourse bed, shaped by regulatory works, was performed at each research section. These were: bottom width, bed depth, bank slope, type of bank protection as well as the bed shading. The measurements of bottom width, bed depth and embankments slope were conducted in the cross-sections spaced every 10 meters. The average value for the entire section was determined on that basis. Also the manner of embankments protection and degree of bed shading were evaluated in the same sections. An assessment of the degree of shading was made visually by standing in the water bed at a point halfway of the total study section.

The species of vascular aquatic plants were identified in each section, both regulated and comparative one. All vascular plants rooted in water for at least $90 \%$ of the growing season, as well as higher plants, freely floating on the water surface or below it, were taken into account [Schaumburg et al. 2006]. Aquatic plant species were determined directly on the research site.

The magnitude of changes in the number of species of aquatic plants was determined based on the study conducted, and their classification was made according to technical changes in the bed of the watercourse. 


\section{RESULTS AND DISCUSSION}

The study demonstrated the occurrence of common aquatic plants, typical for small lowland rivers, in the examined watercourse beds. In the sections not covered by technical interference, 1 to 8 species were detected. These were: Alisma plantago-aquatica L., Berula erecta (Huds.) Coville, Butomus umbellatus L., Elodea canadensis L., Glyceria Maxima (Hartm.) Holmb., Iris pseudacorus L., Lemna minor L., Mentha aquatica L., Myosotis palustris (L.) L. em. Rchb., Nuphar lutea (L.) Sibth. \& Sm., Phalaris arundinacea L., Phragmites communis Trin., Potamogeton natans L., Potamogeton pectinatus L., Sagittaria sagittifolia L., Sparganium emersum Rehmann, Sparganium erectum L. em. Rchb. s.s., Spirodela polyrrhiza (L.) Schleid., Typha L.

The number of species on bed sections transformed as a result of regulatory works ranged from 0-9. The following were identified in these sections: Alisma plantago-aquatica L., Berula erecta (Huds.) Coville, Butomus umbellatus L., Callitriche L., Ceratophyllum demersum L., Elodea canadensis L., Glyceria Maxima (Hartm.) Holmb., Hydrocharis morsus ranae L, Lemna minor L., Myosotis palustris (L.) L. em. Rchb., Nuphar lutea (L.) Sibth. \& Sm., Phalaris arundinacea L., Phragmites communis Trin., Potamogeton crispus L., Potamogeton filiformis Pers., Potamogeton natans L., Potamogeton pectinatus L., Sagittaria sagittifolia L., Sparganium emersum Rehmann, Sparganium erectum L. em. Rchb. s.s., Spirodela polyrrhiza (L.) Schleid., Typha L.

The study demonstrated that aquatic vascular plants in regulated sections of river beds, a few years after the execution of works, showed both an increase in the number of species, their unchanged status as well as the decrease in the number of species. The details in this range are presented in Table 2.

Analysis of the data in Table 2 indicates that the effect of regulatory works on the species composition of vascular aquatic plants communities was differentiated. The research conducted so far indicate that the composition of aquatic plant communities in watercourses are determined by many factors [Bondar-Nowakowska and Hachoł 2010]. Lack of unequivocal relationships in this range means that the evaluation of quantitative changes risk in aquatic plant communities is a difficult task. Therefore, the assignment of suitable values to particular risk factors, i.e. probability of change $(\mathrm{P})$ and the size of the change $(\mathrm{S})$, is of a key significance.

In this study, the classification criteria of these factors were adopted on the basis of the results presented in Table 2 . The probability means the ratio of the number of sections on which identical changes in the number of species were noted, to the total number of sections with the same scope of works. Four-degree scales were accepted in the classification of both factors. A detailed description is presented in Tables 3 and 4 .

The risk register was developed on the basis of probability criteria and the size of changes in the number of vascular aquatic plants species presented in Tables 3 and 4, and on the basis of the data obtained from field studies. It is presented in Table 5. It is a source of information about the risks occurring in the regulatory works.

The information presented in Table 5 relates to partial risk in regulatory works. Risk matrix provides the possibility of a holistic view of the risk problem. The matrix shown in Figure 1 includes all cases recorded in the register (Table 5). It should be interpreted in the following way - the higher the risk is, the greater is the probability of its occurrence. In turn, the greatest threat to aquatic vascular plant communities are the events placed on the right side of the matrix.

It should be noted, based on the matrix presented, that when planning regulatory works in small lowland watercourses, it is not possible to define their consequences in an unequivocal

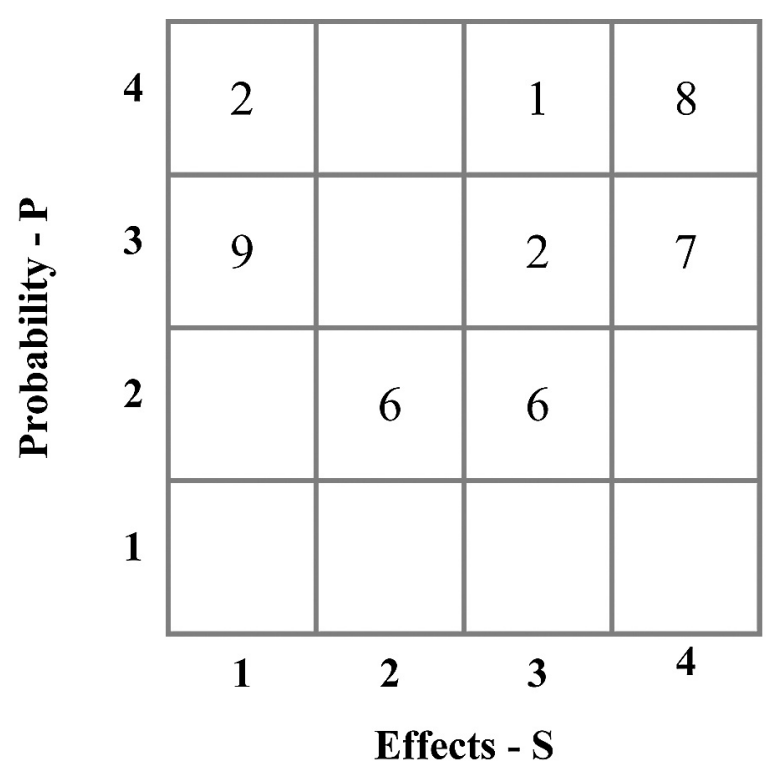

Figure 1. Matrix of probability and results of aquatic vascular plants species changes as a result of regulatory works 


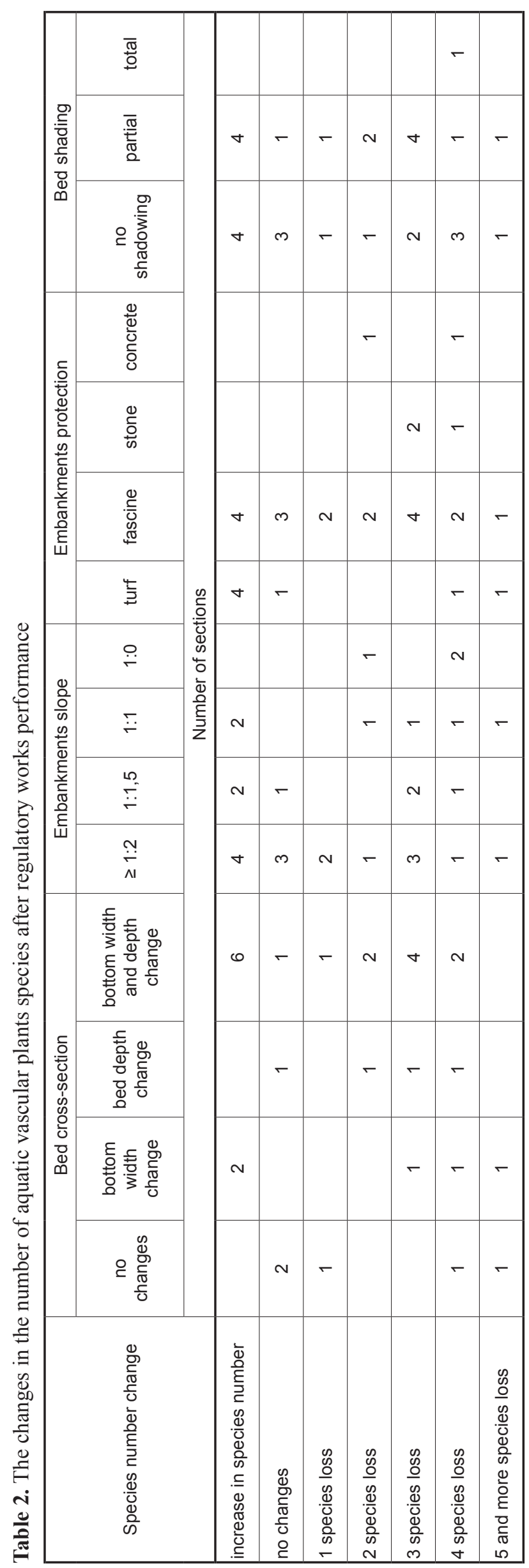


Table 3. Classification of the probability of changes occurrence in aquatic vascular plants species number in regulated watercourses beds $(\mathrm{P})$

\begin{tabular}{|l|l|c|}
\hline \multicolumn{1}{|c|}{ Description of probability } & \multicolumn{2}{c|}{ Size } \\
\hline $\begin{array}{l}\text { Changes occurrence }- \text { very } \\
\text { little probable }\end{array}$ & $\mathrm{P} \leq 0.05$ & 1 \\
\hline Little probable & $\mathrm{P}=0.06-0.19$ & 2 \\
\hline Probable & $\mathrm{P}=0.20-0.49$ & 3 \\
\hline Almost certain & $\mathrm{P} \geq 0.50$ & 4 \\
\hline
\end{tabular}

Table 4. Classification of the size of changes in aquatic vascular plants species number in regulated watercourses beds $(\mathrm{S})$

\begin{tabular}{|l|l|c|}
\hline \multicolumn{1}{|c|}{ Description of changes } & \multicolumn{2}{|c|}{ Size } \\
\hline $\begin{array}{l}\text { Effect of regulatory works } \\
\text { - unnoticeable }\end{array}$ & $\begin{array}{l}\text { Increase, or lack } \\
\text { of species number } \\
\text { change with respect to } \\
\text { comparative section }\end{array}$ & 1 \\
\hline Little effect & One species loss & 2 \\
\hline Significant effect & Two species loss & 3 \\
\hline Severe effect & $\begin{array}{l}\text { Three or more species } \\
\text { loss }\end{array}$ & 4 \\
\hline
\end{tabular}

Table 5. Risk factors size - results of regulatory works and probability of their occurrence on the examined research objects

\begin{tabular}{|c|c|c|c|c|c|}
\hline Performed action & $S$ & $\mathrm{P}$ & Performed action & $S$ & $\mathrm{P}$ \\
\hline \multirow{4}{*}{$\begin{array}{l}\text { Total removing of trees and shrubs from } \\
\text { the embankments and bank zone }\end{array}$} & 1 & 3 & \multirow{4}{*}{ Embankments slope 1:1.5 } & 1 & 4 \\
\hline & 2 & 2 & & 2 & - \\
\hline & 3 & 2 & & 3 & - \\
\hline & 4 & 3 & & 4 & 4 \\
\hline \multirow{4}{*}{$\begin{array}{l}\text { Partial removing of trees and shrubs from } \\
\text { the embankments and bank zone }\end{array}$} & 1 & 3 & \multirow{4}{*}{ Embankments slope $1: 1$} & 1 & 3 \\
\hline & 2 & 2 & & 2 & - \\
\hline & 3 & 2 & & 3 & 2 \\
\hline & 4 & 3 & & 4 & 4 \\
\hline \multirow{4}{*}{ Complete shading left } & 1 & - & \multirow{4}{*}{ Embankments slope 1:0 } & 1 & - \\
\hline & 2 & - & & 2 & - \\
\hline & 3 & - & & 3 & 3 \\
\hline & 4 & 4 & & 4 & 4 \\
\hline \multirow{4}{*}{ No changes in cross-section parameters } & 1 & 3 & \multirow{4}{*}{ Embankments protection with turf } & 1 & 4 \\
\hline & 2 & 2 & & 2 & - \\
\hline & 3 & - & & 3 & - \\
\hline & 4 & 3 & & 4 & 3 \\
\hline \multirow{4}{*}{ Bottom width change } & 1 & 3 & \multirow{4}{*}{$\begin{array}{l}\text { Embankments protection with } \\
\text { fascine }\end{array}$} & 1 & 3 \\
\hline & 2 & - & & 2 & 2 \\
\hline & 3 & - & & 3 & 2 \\
\hline & 4 & 4 & & 4 & 3 \\
\hline \multirow{4}{*}{ Bed depth change } & 1 & 3 & \multirow{4}{*}{ Embankments protection with stone } & 1 & - \\
\hline & 2 & - & & 2 & - \\
\hline & 3 & 3 & & 3 & - \\
\hline & 4 & 4 & & 4 & 4 \\
\hline \multirow{4}{*}{ Change in bottom width and bed depth } & 1 & 3 & \multirow{4}{*}{ Embankments concreting } & 1 & - \\
\hline & 2 & 2 & & 2 & - \\
\hline & 3 & 2 & & 3 & 4 \\
\hline & 4 & 3 & & 4 & 4 \\
\hline \multirow{4}{*}{ Embankments slope 1:2 } & 1 & 3 & & & \\
\hline & 2 & 2 & & & \\
\hline & 3 & 2 & & & \\
\hline & 4 & 3 & & & \\
\hline
\end{tabular}


manner. It can be expected in the case of vascular aquatic plants, whose increase in the number of species will be noted in the regulated bed, the number of species will remain unchanged or will get smaller or larger reduction will be observed. The risk assessment requires consideration of all these aspects. The data from field studies recorded in the matrix indicate that many combinations leading to quantitative changes of aquatic vegetation should be analyzed. Risk analysis should focus on an evaluation of the threats that are the most likely and most important from the point of view of environmental protection. Those that are most important, are located in the upper right corner of the matrix. The study demonstrated that they are complete shading of watercourse bed, and in some cases, bed widening and deepening, embankments slope of 1: 1, 1: 0 , embankments protection with stone material or their concreting. These events should start the efforts aimed to reduce their effect on watercourse bed ecosystem.

This confirms the results obtained in numerous studies. Many authors found that in lowland sites the degree of shading had the highest influence on the quantity, richness and abundance of aquatic plants [Vermaat and de Bruyne 1997, Herb and Stefan 2003, Garbey et al. 2006]. The relationship of aquatic plants with bed width and depth was demonstrated in numerous studies [Ferreira and Moreira 1999, Kõrs et al. 2012, Lorenz et al. 2012]. The bottom width is a factor which determines the life space for aquatic organisms influencing the potential of structural diversity of watercourse bottom [Milner and Gilvear 2012]. The importance of watercourse's depth as a key factor for increased diversity and abundance was found by Chambers and Kaiff [1985]. They showed that the depth influence the amount of light reaching the bottom of the watercourse. Numerous studies demonstrated that the changes in aquatic plant communities are the consequence of bank slope and protection. Higher interference in natural embankment structure causes its higher impact on aquatic plants. It may be the result of a limited supply of nutrients from adjacent areas to the river bed [Qian et al. 2014].

It was assumed in the proposed matrix that the risk is in the range of 1-16. This scale will be adjusted depending on the results of further research. Also the areas of low, moderate and high risk will be indicated in that matrix. At this stage, the matrix can be the supporting tool in making decisions about technical solutions in the transformed bed.

\section{CONCLUSIONS}

The register and matrix of the risk of quantitative changes in vascular aquatic plants communities were elaborated based on the research conducted in watercourses 4-6 years after the execution of the regulatory works. Both the register and the matrix can be used as a source of information at the stage of environmental threats identification in projects relating to the small lowland rivers regulation. The data presented in the register prove that the identification and assessment of risk in such projects is a difficult task due to the complexity of watercourse ecosystem, a diverse range of works, and thus, unpredictable reactions of aquatic plants to the changes in habitat conditions. Therefore, it is important that the developed tools were improved through their continuous verification and completing.

\section{REFERENCES}

1. Biggs B.J.F. 1996. Hydraulic habitat of plants in streams. Regulated Rivers: Research and Management 12: 131-144.

2. Bondar-Nowakowska E. 2010. Reagowanie na ryzyko ekologiczne w konserwowanych ciekach. Zeszyty Problemowe Postępów Nauk Rolniczych 548, 33-44.

3. Bondar-Nowakowska E., Hachoł J. 2010. Wpływ czynników technicznych na stan ekologiczny małych i średnich cieków nizinnych. Infrastruktura i Ekologia Terenów Wiejskich 13, 157-166.

4. Chambers P.A. and Kaiff J. 1985. Depth distribution and biomass of submersed aquatic macrophyte communities in relation to Secchi depth. Canadian Journal of Fisheries and Aquatic Sciences 42, 701-709.

5. Collier K.J. 2002. Effects of flow regulation and sediment flushing on instream habitat and benthic invertebrates in a New Zeland River influenced by a volcanic eruption. River Research and Application 18, 213-226.

6. Cortes R.M.V., Ferreira M.T., Oliveira S.V., Oliveira D. 2002. Macroinvertebrate community structure in a regulated river segment with different flow conditions. River Research and Applications 18, 367-382.

7. Ferreira M.T., Moreira I. 1999. River plants from an Iberian basin and environmental factors influencing their distribution. Hydrobiologia 415, 101-107.

8. Garbey C., Thiébaut G., Muller S. 2006. An experimental study of the plastic responses of Ranunculus peltatus Schrank to four environmental param- 
eters. Hydrobiologia 570, 41-46.

9. Herb W.R., Stefan H.G. 2003. Integral growth of submersed macrophytes in varying light regimes. Ecological Modelling 168, 77-110.

10. Kõrs A., Vilbaste S., Käiro K., Pall P., Piirsoo K., Truu J., Viik M. 2012. Temporal changes in the composition of macrophyte communities and environmental factors governing the distribution of aquatic plants in an unregulated lowland river (Emajõgi, Estonia). Boreal Environment Research 17, 460-472.

11. Lorenz A.W., Korte T., Sundermann A., Januschke K., Haase P. 2012. Macrophytes respond to reachscale river restorations. Journal of Applied Ecology 49, 202-212.

12. Milner V.S., Gilvear D.J. 2012. Characterization of hydraulic habitat and retention across different channel types; introducing a new field-based technique. Hydrobiologia 694, 219-233.

13. O'Hare J. M., O'Hare M. T., Gurnell A. M., Dunbar M. J., Scarlettc P. M., Laizé C. 2011. Physical constraints on the distribution of macrophytes linked with flow and sediment dynamics in British rivers. River Research and Applications 27, 671-683.

14. Petkovska V., Urbanič G. 2015. Links between morphological parameters and benthic invertebrate assemblages, and general implications for hydro- morphological river management. Ecohydrology 8, 67-82.

15. Pritchard C.L. 2011. Risk Management - Concepts and Guidance. ESI International. Virginia.

16. Qian J., Zhang L.-P., Wang W.-Y., Liu Q. 2014. Effects of Vegetation Cover and Slope Length on Nitrogen and Phosphorus Loss from a Sloping Land under Simulated Rainfall. Polish Journal of Environmental Studies 23 (3), 835-843.

17. Sand-Jensen K. 1998. Influence of submerged macrophytes on sediment composition and nearbed flow in lowland streams. Freshwater Biology 39, 663-679.

18. Schaumburg J., Schranz C., Stelzer D., Hofmann G., Gutowski A., Foerster J. 2006. Instruction Protocol for the ecological Assessment of Running Waters for Implementation of the EC Water Framework Directive: Macrophytes and Phytobenthos. Bavarian Environment Agency, München.

19. Vereecken H., Baetens J., Viaene P., Mostaert F., Meire P. 2006. Ecological management of aquatic plants: effects in lowland streams. Hydrobiologia 570, 205-210.

20. Vermaat J.E., de Bruyne R.J. 1993. Factors limiting the distribution of submerged waterplants in the lowland River Vecht (The Netherlands). Freshwater Biology 30, 147-157. 